\title{
The Impact of Housing Assistance on the Employment Outcomes of Labour Market Programme Participants ${ }^{\mathrm{i}}$
}

\author{
Urban Studies, 49(4), pp. 821-844 \\ by \\ Simon Feeny, RMIT University \\ Rachel Ong, Curtin University \\ Heath Spong, University of Iowa \\ Gavin Wood, RMIT University
}

\section{Introduction}

This paper examines whether the employment outcomes of labour market programme (LMP) participants in Australia vary according to whether they receive housing assistance (HA). In recent decades, there has been a shift in policy away from passive receipt of income support towards an emphasis on economic participation. This has led to the development of mutual obligation policies in many countries such as Australia, the United Kingdom (UK), the United States (US), Canada and New Zealand. These policies are based on the concept of "reciprocal obligation" where receipt of unemployment benefits is conditional on active participation in LMPs (Burgess, 2000: 173-174).

Following a series of pilot schemes, and the 1997 "Work for the Dole" legislation, Mutual Obligation Activities (MOAs) were formally implemented in Australia in July 1998. Under these reforms, Australians unemployed for six months or longer and receiving an unemployment benefit must participate in a LMP to remain eligible for these benefits (Yeend, 2004). MOA requirements initially applied only to 18-to-24 year olds who have been unemployed for six months. Unemployment benefits for claimants aged 21 years or over were referred to as Newstart Allowance and as Youth Allowance for those aged under 21 years. In 1999, MOA requirements were extended to recipients aged 25-34 who had been unemployed for 12 months (Curtain, 2000). From 2002, MOA requirements were standardised for all Newstart or Youth Allowance recipients aged under 50 who had been unemployed for six months or more (Treasurer, 2002).

1997 also saw the introduction of the New Deal by the UK government (McQuaid and Greig, 2004). Under the UK programme, 18-to-24 year olds who had been in receipt of unemployment benefit for six months and 25-to-59 year olds who had been receiving unemployment benefit for two years were subject to mandatory participation in LMPs in return for continued benefit receipt (Dickens et al., 2000). ${ }^{\text {ii }}$ Around the same time the 1996 Personal Responsibility and Work Opportunity Reconciliation Act (PRWORA) was passed in the US requiring recipients to work in order to receive welfare payments. These US reforms also embrace lifetime limits on receipt of income support (see Blank, 2002 for details).

A series of studies conducted by policy analysts and academics have explored the impact of Housing Assistance (HA) on the employment outcomes of LMP participants. Most of these studies suggest that LMP initiatives are more likely to result in positive outcomes if those enrolled are receiving HA. Five reasons have been advanced to explain these findings. First, HA recipients have more secure and stable housing arrangements that make the search for employment opportunities more productive. So, for example, an address for correspondence and security of tenure in public housing can aid transitions into employment by making it easier to take 
advantage of programmes designed to help prepare for and hold a job (Van Ryzin et al., 2003). ${ }^{\text {iii }}$ Second, HA can help the unemployed to relocate closer to employment opportunities where the housing cost burden is more onerous (Fletcher et al., 2008). Third, HA can improve the ability of low income workers to keep jobs by freeing up resources that can be used to meet work-related expenses such as childcare and transportation (Verma and Hendra, 2003). Fourth, concentrations of joblessness are commonplace in areas dominated by social housing (Brennan et al., 2000). If mandatory participation in LMPs does increase labour market attachment it effects will be more visible and detectable in areas dominated by asocial housing (Dickens et al., 2000). Finally, if HA recipients are more prone to low-income traps that deter labour market participation, reforms that introduce work obligations can have a potentially larger impact upon this group because they override blunt work incentives (Verma et al., 2003).

Some of the institutional arrangements governing the delivery of HA in the US are idiosyncratic (section 8 housing vouchers, for example), and might shed some doubt on the relevance of all these pathways in other countries. But the last proposition above is particularly relevant in the Australian context. The evidence indicates that Australian HA recipients' poverty and unemployment traps are generally 'deeper' than those experienced by other income support recipients (Wood et al., 2005; Dockery et al., 2008a). Indeed HA clients' work incentives have become a major concern among Australian policy makers. This is reflected in the 2003 Commonwealth-State Housing Agreement which required state and territory governments to reform rent-setting formulae in ways consistent with the promotion of economic participation among public housing tenants. Its successor, the 2009 National Affordable Housing Agreement, aspires to house all Australians in affordable housing that contributes to economic participation (Council of Australian Governments, 2009, p3). Mutual obligation policies might then generate a relatively large lift in employment participation among clients of HA programmes in Australia, and if findings confirm this expectation, they should be of particular interest to policy makers. The issue also deserves special attention in view of declining employment participation rates among particular groups of HA recipients. This decline has been an especially steep one among males in public housing, despite a stronger Australian labour market in recent years (Wood et al., 2009). ${ }^{\text {iv }}$

To explore these policy issues, we take a sample of 684 unemployed persons that have reported participation in MOAs and labour market programmes. We examine whether subsequent employment profiles are superior for recipients of HA. In summary, we find contrary to US studies, that participants in Australian LMPs have employment outcomes that do not vary with the HA status of participants. We believe this is due to differences in institutional arrangements governing the delivery of HA that are critical to welfare-to-work outcomes. Countries that are considering reform of HA programmes with a view to promoting employment might be welladvised to consider the governance arrangements shaping access to and delivery of HA.

The remainder of this paper is structured as follows. Previous literature comparing the labour market outcomes of welfare-to-work reforms by HA status is summarised in Section 2. The data and modelling approach are described in Section 3 while empirical results are presented and interpreted in Section 4. Finally, Section 5 concludes with policy implications arising from the research. 


\section{Background}

Australia has historically had a market-based housing system with homeownership rates that have hovered around 70\% since the 1960s. Nevertheless, there are two major HA programmes that feature prominently in Australian housing governance arrangements. Public housing is a rationed form of assistance provided by State governments; it is housing for those in most need, and at rents that are set at a fixed percentage - typically $25 \%$ - of assessable income. There is therefore a rent subsidy benefiting tenants in public housing provided their incomes are such that the income-related formula results in a rent below market rent. Public housing in Australia has historically provided security of tenure to its tenants, an attribute that is absent in Australian private rental housing, which has no tradition of tenancy regulation. Commonwealth Rent Assistance (CRA) is a non-rationed form of assistance provided by the Federal government to income support payment recipients renting from private landlords and Community Housing Organisations. ${ }^{\text {v CRA }}$ entitlement is fixed across the income range within which the household retains eligibility for the income support payment that acts as a 'passport' to CRA eligibility. It is then withdrawn at the same taper rate as is applied in determining withdrawal of the passport income support payment.

In 2006, there were 1.1 million recipients of CRA and 618,000 tenants in public housing. There were 187000 on public housing waiting lists in the same year (Steering Committee for the Review of Government Service Provision, 2007). HA is therefore a welfare programme that touches on the lives of hundreds of thousands of Australians. $^{\text {vi }}$ It has unsurprisingly become an issue of relevance in debates concerning welfare dependency and rates of economic participation among those on welfare rolls.

Standard choice theoretic economic analysis of labour supply suggests that the impacts of HA programmes on labour supply are ambiguous. The typical approach assumes that workers make a choice between work hours and leisure at a fixed or exogenously determined wage rate. The introduction of income-related HA programmes results in substitution and income effects that can impact on labour supply in different directions. If leisure is a normal good such that hours of leisure increase with increments in real income, then the choice theoretic analysis of labour supply unambiguously predicts that assistance will blunt work incentives and reduce rates of economic participation among HA recipients. As a result, those eligible for HA are thought to be a group particularly prone to welfare dependency. This type of economic analysis has informed the direction of welfare-to-work reforms in various countries. These reforms often include making receipt of welfare conditional upon active participation in LMPs.

However, the implications of choice theoretic models in the HA context may not be as straightforward as suggested above. Murray (1980) and Schone (1992) point out that assistance provided in the form of public housing is closer to a 'pure' in-kind transfer, where assistance is provided in the form of a 'take it or leave it' bundle of shelter services, than a 'pure' cash transfer in which support is received in the form of a cash sum that is spent by the recipient on consuming goods and services. The distinction is important because in-kind transfers can cause work effort to increase if the assistance is provided in a form that is complementary to work. Furthermore, inkind transfers typically impose more of the in-kind transfer than would be chosen at market prices and an equivalent cash transfer. Increases in earnings raise the value of 
the in-kind transfer, and drive real income up by more than the dollar value of the boost to earnings. The incentive to increase hours of work is then greater under the inkind assistance than with an equivalent cash transfer (Murray, 1980; Schone, 1992).

The recent spate of studies examining the employment impacts of HA has been motivated by policy reforms aiming to improve employment participation among welfare recipients. The literature is dominated by US studies. Many of these studies have used experimental approaches where families have been randomly assigned between treatment groups, which are subject to policy reforms, and control groups that continue under the existing policy regime. The experimental approach was made possible when the US Department of Health and Human Services granted waivers to some US states on adopting welfare policy changes, but only on condition that those states conducted random-assignment evaluations of any changes. Within counties or welfare office zones, some welfare receiving families were randomly subjected to the new welfare policies, thus creating a treatment group. Families on welfare but not subjected to the new policies form the control group. Studies incorporating these random-assignments find that HA recipients exhibit superior employment outcomes relative to welfare recipients not receiving HA. Findings in support of this conclusion can be found in Lee et al., (2003) using data for Indiana and Delaware, Miller et al., (1997) and Miller (1998) using data for Minnesota, Verma et al., (2003) for the states of Minnesota and Connecticut and Riccio and Orenstein (2001) using data for Atlanta.

But Susin (2005) and Harkness and Newman (2006) obtain different findings. They adopt quasi-experimental approaches that create control groups by matching the personal characteristics of HA recipients with those of a sample of welfare programme participants ineligible for HA. Susin (2005) finds that housing subsidy programs reduce individual earnings by roughly 15 percent while Harkness and Newman (2006) suggest that employment outcomes for single mothers receiving housing assistance did not statistically differ from those ineligible.

Results from non-experimental studies are less conclusive. McQuaid and Greig (2004) estimate an employment model using a small sample survey of 306 unemployed jobseekers from 13 employment service job centres in Scotland, and find that residence in public housing has neither a positive or negative impact on employment outcomes. Similarly, Van Ryzin et al. (2003) and Corcoran and Heflin (2003) find that HA has little impact, either way, on the employment and earnings of welfare recipients in New York and Michigan state respectively.

A further group of studies compares employment and related outcomes by HA status, but once clients have left welfare rolls. Verma and Hendra (2003) suggest that leavers in Los Angeles County with tenant-based assistance were somewhat more likely to have positive employment outcomes. In Massachusetts Nagle (2003) offers evidence indicating that HA recipients were somewhat more likely to be employed but with a lower average hourly wage. Stronger results are presented in Friedman et al., (2003) who find that HA is essential in the transition from welfare to work, and from homelessness to independent living in secure housing.

While this paper is the first Australian study to consider the combined effect of HA and compulsory participation in LMPs on employment outcomes, there have been two other important and related contributions. Firstly, Richardson (2002) estimates a proportional hazard model to measure the impact of MOA on the longterm unemployed and their unemployment spells. The study reveals that while MOAs have some marginal impact on the probability of leaving welfare, the programme did not affect the average duration that individuals were actually on welfare rolls 
(Richardson, 2002, pp.407). Secondly, Lim (2008) evaluated the impacts of MOAs on mature age Newstart Allowance recipients' employment participation decisionmaking using a longitudinal dataset created to administer income support payments for the unemployed. The study reveals that only 2.2 per cent of recipients participated in a MOA program, completed it, took up paid employment and subsequently left welfare.

We consider a sample of long-term unemployed Australians and ask whether the receipt of HA shapes their employment outcomes. We also explore whether the type of HA received matters. A panel dataset is employed to address these key research questions. The following section describes data sources and model specifications.

\section{Data and Methodology}

\section{Data and Sample}

This paper utilises waves 1 to 6 of the Household Income and Labour Dynamics in Australia (HILDA) Survey covering the period 2001-06. The HILDA Survey is a nationally representative panel survey of Australian households and individuals. The HILDA Survey comprehensively covers the three inter-related areas of income, labour and household dynamics. Among other things, the survey contains a myriad of variables describing labour market histories, LMP participation, housing circumstances and socio-demographic characteristics, all of which are pertinent to the present analysis. The timeframe of data collection begins not long after the Australian introduction of MOAs in 1998.

Our sample is restricted to all 'compulsory' working age LMP participants. Working age persons are non-dependent persons aged 15-64 during the timeframe 2001 - 2006. ${ }^{\text {vii }}$ Compulsory LMP participants are persons in the labour force, that is available for and seeking work, who have been required by Centrelink or a Job Network provider to participate in a LMP in the financial year leading up to their wave of interview. ${ }^{\text {viii }}$ Centrelink is the Australian government agency administering Federal income support payments to eligible persons such as unemployed persons on low incomes, and a Job Network provider (replaced by Job Services Australia in July 2009) is an organisation providing employment services that assist jobseekers to find work. The range of eligible MOA activities can be grouped under three broad categories. Firstly, Employment and community participation covers activities such as Work for the Dole, community work or any form of paid part-time employment. Secondly, the Training category include defence force reserve or approved language, literacy and numeracy schooling (Centrelink, 2008). The third category, Employment assistance, is a one-to-one programme that helps prepare unemployed persons for work opportunities by guiding job search, helping with the preparation of resumes and so on (Lim, 2008).

A person is defined as a HA recipient (public housing tenant or CRA recipient) if the person received HA at any time between waves 1 to 6 . Public housing tenants are readily identifiable from the dataset as renters whose landlord is a state housing authority. CRA recipients are not recorded in the dataset. However, eligibility for CRA can be imputed based on the respondents' answers to questions regarding their housing tenure, rent payments and receipt of income support payments (Wood and Ong, 2008). 
A person-period data set is created by including each wave from the point in time that unemployed persons were required to enrol in a LMP between 2001 and 2006. There were 684 persons enrolled during the sample period but 229 or 33.5\% have attrited at some point since first observed as a LMP participant. However, the attrition rates among the LMP participants receiving HA (32\%) and other LMP participants (35\%) are not statistically significantly different, suggesting that the process of attrition is not correlated with HA status. The sample of 684 persons is retained, though for approximately one-third of the sample, the number observations is less than the maximum possible. ${ }^{\text {ix }}$

Of this sample of 684 MOA participants, 310 (45\%) are HA recipients, CRA being the more common form of HA received. ${ }^{\mathrm{x}}$ A MOA participant may have enrolled in more than one programme during the time period of analysis. The Employment assistance category is the largest programme regardless of HA status. There are different patterns in the other categories, with HA recipients much more likely to enrol in the employment and community participation and training categories. These differences are statistically significant.

We use a quasi-experimental study design. It treats the sample of LMP participants as if they had been randomly assigned into 2 groups - participants (the 'treatment' group) and non-participants (the 'control' group) in HA programmes. While HA status might have employment effects among LMP participants, inferior employment outcomes will often lead to eligibility for HA. The threat this poses to the study design's credibility is tempered by the observation that our sample is drawn exclusively from the pool of unemployed. The sample is then comprised of individuals that are equally likely to be eligible for HA by virtue of their labour market status. Nevertheless, the HA variables are lagged in some of the empirical modelling as a precaution.

The quasi-experimental study design is more robust if the treatment and control groups meet two criteria. First, at any point in time the treatment and control groups should be indistinguishable with respect to measured characteristics shaping employment outcomes, as would be expected with a randomised experimental study design. This expectation is investigated in Table 1, which compares the key characteristics of HA and non-HA participants as measured when first enrolled in LMPs. Those admitted on to HA programmes are more likely to be female, younger (under 34 years) and indigenous. They are also more likely to be sole parents and have very young children (0-4 years). Labour market histories are also different. HA recipients have spent less time in employment - and more time unemployed - since leaving full time education.

\section{[Table 1 here]}

Second, as we are conducting a comparison of employment profiles over time intervals subsequent to enrolment in LMPs, our concern is not just with cross section differences in profiles, as in Table 1 . The research approach is more robust if the charcateristics of treatment and comparison groups do not diverge over the time interval studied (Meyer, 1995). ${ }^{\mathrm{xi}}$ Table 2 computes the difference in key time-varying demographic and socioeconomic variables over the time period separating enrolment in LMPs (the 'starting' observation) and the most recent observation (the 'end' observation) - wave 6 in most cases. ${ }^{\text {xi }}$

Column 3 shows whether there have been significant changes over time within the HA group. Column 6 shows the same within group estimates for the non- 
HA group. Comparing the two columns, it is evident that both groups registered a fall in the proportion of singles and increases in the incidence of couples with dependents, those holding post-school qualifications and rates of disability. There are a few divergent trends. An increasing proportion of households receiving HA are couples with dependents and families with three or more children, but the opposite trend is apparent among other LMP participants. A declining proportion of HA recipients are childless, but an increasing proportion of other LMP participants are childless.

Column 7 presents tests of significance in difference-in-difference estimates. They suggest that changes in the composition of the two groups have been generally similar over the period analysed. But statistically significant difference-indifference estimates are evident with respect to the incidence of couples with dependents, parenting three or more children, the presence of children aged less than ten years and childless households. The correlation between presence of children and HA status is unsurprising as households can become eligible for CRA if they receive Family Tax Benefit, an Australian transfer programme offering assistance to parents satisfying income and asset means tests. Since the presence of children can impact labour supply choices, it is important to have controls for these personal characteristics in the employment models.

Of particular importance to the current paper are changes in rates of employment. There is a large lift in employment rates from 50\% to 63\% (a 13 percentage point increase) among those never eligible for HA. While starting employment rates among HA recipients are lower at $29 \%$, there is a somewhat higher 16 percentage point increase to $45 \%$. However, these trend increases are not significantly different between the two groups (even at the $10 \%$ level of significance). Among those employed at both start and end dates there are also large increases in weekly wages - from \$381 to \$509 for HA recipients and from \$564 to \$696 among others. Again, the trend increases are not significantly different between the two groups. This paper proceeds by employing panel model techniques to more rigorously compare employment profiles.

[Table 2 here]

\section{Methodology}

A random effects logit panel model of employment is estimated. Given the existence of a latent continuous dependent variable $Y_{i t}^{*}$ the model has the specification;

$Y_{i t}^{*}=\alpha^{\prime} H_{i}+\beta^{\prime} X_{i t}+u_{i}+\varepsilon_{i t}, \quad i=1,2, \ldots . . N t=1,2 \ldots \ldots . T$

$Y_{i t}=1$ if $Y_{i t}^{*}>0$

$Y_{i t}=0$ if $Y_{i t}^{*} \leq 0$

where $H_{i}$ is a HA status variable, $X_{i t}$ is a vector of control variables, $u_{i}$ is the unobserved individual specific effect, $\varepsilon_{i t} \sim \mathrm{N}\left(0, \sigma^{2}\right)$ and $u_{i} \mid H_{i,} X_{i t} \sim\left(0, \psi^{2}\right)$. ${ }^{\text {xii }}$ The exogeneity assumptions are:

$$
E\left(u_{i} \mid H_{i} X_{i t}\right)=0=E\left(\varepsilon_{i t} \mid H_{i}, X_{i t}, u_{i}\right)
$$

The vector of control variables include type of LMP, age, gender, disability status, household type, number and age of children, ethnicity, location, educational qualifications and labour market history. (See table A1 in the appendix for variable definitions and measurement.) Calendar year dummies (2002 omitted) are introduced to capture changing labour market conditions - the national unemployment rate fell 
from $6.1 \%$ in 2002 to 4.5\% in 2006 (Australian Bureau of Statistics, 2009). Tables 1 and 2 suggest that the exogeneity assumptions may not hold because of omitted variables. We therefore adopt an instrumental variable (IV) approach (see Mundlak, 1978; Skrondal and Rabe-Hesketh, 2004 and Baxter et al. 2008) in which the deviation from each LMP participant's mean housing assistance $\left(H_{i(t-1)}-\bar{H}_{i}\right)$ and $\bar{H}_{i}$ is included as in the following model specification;

$Y_{i t}^{*}=\alpha_{1}^{\prime}\left(H_{i(t-1)}-\bar{H}_{i}\right)+\alpha_{2}^{\prime} \bar{H}_{i}+\beta^{\prime} X_{i t}+u_{i}+\varepsilon_{i t}, i=1,2, \ldots \ldots . . N t=1,2 \ldots \ldots . . T$

Equation (3) collapses to the original random effects model if $\alpha_{1}^{\prime}=\alpha_{2}^{\prime}=\alpha^{\prime}$. The deviation $\left(H_{i(t-1)}-\bar{H}_{i}\right)$ is an IV because it is correlated with $H_{i t}$ but uncorrelated with the random intercept $u_{i}$. An unobservable such as innate ability that varies across LMP participants and could be correlated with HA status, will not vary across time for the same LMP participant and cannot therefore be correlated with $\left(H_{i(t-1)}-\bar{H}_{i}\right)$. In

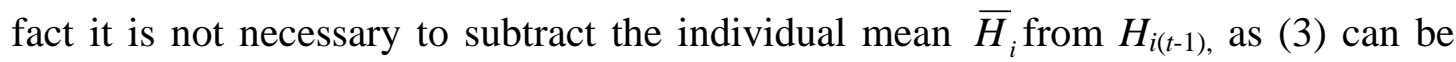
rewritten as:

$Y_{i t}^{*}=\alpha_{1}^{\prime}\left(H_{i(t-1)}\right)+\left(\alpha_{2}^{\prime}-\alpha_{1}^{\prime}\right) \bar{H}_{i}+\beta^{\prime} X_{i t}+u_{i}+\varepsilon_{i t}, \quad t=1,2 \ldots \ldots . . T$

The estimate $\hat{\alpha}_{1}^{\prime}$ is the 'within' LMP participant effect derived from comparing employment status for the same LMP participant when eligible for HA in some waves and not others. The intuition behind the instrumental variable approach is that the $\bar{H}_{i}$ variable will capture the influence of unobservables that act as partial determinants of labour market outcomes. So for example, innate ability could systematically vary between the unemployed with sustained spells on HA and those with little or no eligibility. On the other hand, the $H_{i(t-1)}$ variable exploits the longitudinal nature of the data, in particular the same person's transitions on and off HA programmes, to detect the independent effect that HA has on employment outcomes. Time-invariant characteristics like innate ability will be constant for the same person, and will not therefore be confounded with that same person's transitions on and off HA.

There is considerable churning in and out of HA programmes to permit estimation of $\hat{\alpha}_{1}^{\prime}$, the 'true effect' of HA. The percentage of those eligible for HA in year $t+1$ but not receiving HA in year $t$ varies from 12\% in 2004 to $20 \%$ in 2002 . Those not enrolled in HA programmes in year $t+1$, but receiving HA in year $t$ varies from $15 \%$ in 2004 to $27 \%$ in 2003.

\section{Results and Interpretation}

Table 3 reports the results from estimation of the random effects panel model (equation 1) and the IV panel model (equation 4). ${ }^{\text {xiv }}$ It lists coefficient estimates and the calculated marginal effect at the sample mean. The key emphasis of this paper is on whether HA improves the employment prospects of LMP participants. Results from estimation of the random effects model indicate that those enrolled in HA programmes have a 22 percentage points lower probability of employment, a marginal effect estimate that is highly significant. This finding is evident despite controls for gender, the presence of young children, type of LMP programme, age, ethnicity and labour market history - all personal characteristics that we know differ by HA status (see Tables 1 and 2), and might also be expected to impact labour market outcomes. 
But as pointed out in our discussion ofmodel specification in section 3, it is likely that this 22 percentage point estimate captures the impact of unobservables that are correlated with both HA eligibility and labour market outcomes.

So we now turn to the IV estimates reported in the final two columns of Table 3. The coefficient $\hat{\alpha}_{1}^{\prime}$ is positive with a marginal effect estimate suggesting that employment probabilities are raised by 12 percentage points. But the estimate is statistically insignificant. In contrast, the estimate $\left(\hat{\alpha}_{2}^{\prime}-\hat{\alpha}_{1}^{\prime}\right)$ is highly statistically significant and negative. Results from these specifications indicate that unmeasured heterogeneity makes the HA variable $\left(H_{i t}\right)$ endogenous, and that the unmeasured variables depress the post-LMP participation employment profiles of those enrolled in HA programmes. However, once we account for endogeneity of the HA variable our estimates suggest that labour market programme participants receiving HA are no more likely to obtain better (or worse) employment outcomes than other labour market program participants. These findings imply that either HA is unimportant for employment outcomes, or that any incentive effects depressing work effort are offset by employment promoting benefits. Unpacking the various positive and negative causal connections provided by HA remains an area for future research. ${ }^{\mathrm{xv}}$

A number of other results are worthy of comment. The type of LMP and the timing of post-LMP participation observations are highly significant and important. Enrolment in Employment and community participation is associated with a 29 percentage point lower probability of employment (relative to enrolment in Employment assistance programmes). Unsurprisingly, as labour market conditions strengthened between 2002 and 2006 employment prospects improved; a LMP participant has a 32\% higher probability of employment in 2006 as compared to 2002.

The models include a number of socio-demographic variables. Age and an age squared variable is included to capture a non-linear relationship between age and the probability of being employed. Results indicate that the probability of employment increases with age up to 24 years but then starts to fall. This inverted-U shaped relationship is consistent with other studies. ${ }^{\text {xvi }}$ Disability lowers employment probabilities by 29 percentage points, which is the second highest impact of any dichotomous variable. The presence of children, particularly very young dependents, might be expected to positively impact on the probability of employment, but turns out to be unimportant in this model. Since over $50 \%$ of the sample are singles and over two-thirds are childless we may have an insufficient number of parents to detect any significant influence. Ethnicity variables are also unimportant but the indigenous account for only $6 \%$ of the sample, so small sample numbers might be an issue here as well. Residence in a major city location raises the probability of employment by 20 percentage points relative to location in inner regions, confirming the superior employment opportunities that usually exist in the 'deeper' labour markets of major urban areas.

Among the human capital variables, qualifications are unimportant, but labour market history is a large and significant influence. Over 50\% of the sample have no post-school qualifications. On the other hand there is considerable variation in employment histories. Just over $10 \%$ of the sample has never worked, while around $63 \%$ have worked for more than one-half of their careers to date. This variation in employment history is an important influence. A one standard deviation increase in time in paid work (from a mean $62 \%$ to $91 \%$ of time since leaving full time education) increases the predicted probability of employment (in 2006) from 55\% to $65 \%$. ${ }^{\text {xvii }}$ Conversely a history of unemployment seriously damages job prospects. A one standard deviation increase in time unemployed (from a mean $20 \%$ to $46 \%$ ) 
lowers the predicted probability of employment by 6 percentage points (55\% to 49\%). LMP participants that have been unemployed for long periods experience depreciation of their human capital, and can also become discouraged, hence searching for employment less intensively. It is also possible that employers use employment history as a signal of reliability and capability. Whatever the reason the employment 'track records' of LMP participants is clearly a critical factor shaping labour market outcomes.

\section{[Table 3 here]}

Table 4 explores whether unpacking the HA variable into its constituent programmes (public housing and CRA) offers a richer interpretation. Different findings might be anticipated in view of the varying institutional arrangements that govern eligibility and entitlement with respect to the two programmes. Public housing is rationed with eligible applicants entering queues that are so lengthy that wait times often exceed 12 months. Eligibility for public housing must be maintained in order to retain a position in the queue and this can deter applicants from accepting job offers. Transitions into public housing might then be more powerfully associated with lifts in rates of employment than CRA, where entitlement is automatic if eligibility criteria are met. But the IV variables are again positive and insignificant; transitions onto either HA programme appears to have no significant independent effect on employment participation. On the other hand, we find that the mean CRA variable $\bar{C}_{i}$ is significant and once again negative while the mean public housing variable $\bar{P}$ is insignificant, though again negative. In view of the much larger number of CRA recipients in our sample, this last result is perhaps unsurprising. It is also noteworthy that findings with respect to socio-demographics, human capital, employment history and type of LMP are consistent with those reported in Table 3.

[Table 4 here]

\section{Conclusion and Policy Implications}

The mutual obligation programme established in Australia during the late 1990s reflects part of a growing international emphasis on economic participation by welfare recipients. Using a sample of unemployed Australians who have been required to participate in LMPs, this paper has examined the impact of HA on employment outcomes. Results from the estimation of random effects panel models provide little evidence that HA has any independent impact on the probability of employment of LMP participants - either positive or negative.

These findings contrast with the positive results presented in a number of US random experiment and non-experimental studies. We put forward two possible explanations for the different findings. Firstly, CRA is the main HA programme received by the Australian HA group and it is an entitlement available to all income eligible residents of private rental housing. The US equivalent, housing voucher programmes, is rationed with income eligible renters joining queues. The sample design in US studies is typically restricted to renters enrolled in welfare programmes. If most are eligible for vouchers, as seems likely, the HA group will be people that have reached the top of queues before or during the study time frame. The comparison group is then eligible welfare recipients still waiting in the queue. Those in queues are 
vulnerable to welfare locks - they have an incentive to reject job offers or job search less intensively to preserve eligibility (Dockery et al., 2008b). The HA variable in US studies could then be picking up welfare lock effects rather than positive synergies between welfare-to-work reforms and enrolment in HA programmes. If this explanation is valid, it follows that our Australian findings will have some relevance to other countries where welfare-to-work reforms are accompanied by HA programmes that are administered on an eligibility basis rather than rationed. Among English-speaking countries, for example, both the UK and New Zealand have introduced welfare-to-work reforms but their important income-related HA programmes (Housing Benefit in the UK, Accommodation Supplement in New Zealand) are entitlements where assistance is automatically provided to all those demonstrating eligibility.

Secondly, the scope of the early Australian reforms was targeted on different groups as compared to their US counterparts. In the US, 1996 Federal reforms introducing mandatory work requirements and maximum time limits for receipt of welfare assistance were targeted on families with dependent children (Blank, 2002). As in the UK, compulsory LMP participation under Australia's mutual obligation policies were originally targeted at young adults belonging to the pool of long-term unemployed. Those on disability support pensions and sole parent pensions were outside the scope of welfare-to-work reforms. Sole parents are particularly prone to poverty and unemployment traps if receiving HA in the form of public housing (Wood et al. 2009). It may be that as this group are brought within the scope of mutual obligation policies, the comparative employment profiles of HA recipients will begin to resemble those detected in US studies. However, on the basis of the empirical work conducted here we can find no evidence for synergies between Australian HA programmes and welfare-to-work reforms.

Both these explanations emphasise cross country differences in institutional arrangements. If valid they imply a cautious approach when assessing evidence drawn from the impact of policy programmes in other countries. Policies that are effective in one institutional setting can prove ineffective under different institutional arrangements. In countries with relatively large social housing tenures and administered allocation mechanisms there are other reasons to doubt synergies between HA and welfare to work reforms. Rigid allocation rules can impede labour mobility among social housing tenants and reduce the effectiveness of LMP among those tenants.

A further important policy finding from this paper is that concerning the effectiveness of alternative LMP activities. LMP participants undertaking Employment and Community Participation experience a lower probability of employment than those undertaking Employment assistance. Interestingly, Australian Employment Assistance activities are most like the US form of obligatory activity, which invariably seem to deliver a superior employment outcome (Miller, 1998; Riccio and Orenstein, 2001). Possible cream skimming or self selection effects could explain the finding in the Australian context. 


\section{Tables}

Table 1: Socio-demographic characteristics in wave when first enrolled in LMP, by HA status, column per cent unless stated otherwise

\begin{tabular}{|c|c|c|c|c|}
\hline Characteristic & & HA & No HA & All \\
\hline Female & & 42.9 & $34.5^{* *}$ & 38.3 \\
\hline \multirow[t]{3}{*}{ Age band } & $15-19$ & 11.3 & $9.1 *$ & 10.1 \\
\hline & $20-34$ & 40.6 & $37.4 *$ & 38.9 \\
\hline & 35 or over & 48.1 & 53.5 & 51.0 \\
\hline \multirow[t]{5}{*}{ Income unit type } & Couple with dependents & 20.3 & 18.7 & 19.4 \\
\hline & Couple without & & & 17.3 \\
\hline & dependents & 15.8 & 18.4 & \\
\hline & Sole parent & 12.6 & $5.3 * *$ & 8.6 \\
\hline & Single & 51.3 & 57.5 & 54.7 \\
\hline \multirow[t]{4}{*}{ Number of dependent children } & Zero & 67.1 & $75.9 *$ & 71.9 \\
\hline & One & 16.5 & $8.8 * *$ & 12.3 \\
\hline & Two & 10.3 & 10.4 & 10.4 \\
\hline & Three or more & 0.1 & 0.0 & 5.4 \\
\hline \multirow[t]{3}{*}{ Mean number of children aged } & $0-4$ years & 0.2 & $0.1 * *$ & 0.15 \\
\hline & 5-9 years & 0.2 & 0.1 & 0.15 \\
\hline & $10-14$ years & 0.1 & 0.1 & 0.14 \\
\hline \multirow[t]{4}{*}{ Ethnicity $^{\mathrm{a}}$} & Australian non-Indigenous & 66.5 & 73.0 & 70.0 \\
\hline & Australian Indigenous & 9.4 & $3.2 * *$ & 6.0 \\
\hline & Main English-speaking & 7.1 & 8.8 & 8.0 \\
\hline & Other & 17.1 & 15.0 & 15.9 \\
\hline \multirow[t]{3}{*}{ Region $^{b}$} & Major city & 58.1 & 54.3 & 56.0 \\
\hline & Inner region & 25.2 & 29.1 & 27.3 \\
\hline & Outer or remote region & 16.8 & 16.6 & 16.7 \\
\hline \multirow[t]{3}{*}{ Highest educational qualification } & Bachelor degree or higher & 8.4 & 10.4 & 9.5 \\
\hline & $\begin{array}{l}\text { Other post-school } \\
\text { qualification }\end{array}$ & 33.9 & 36.6 & 35.4 \\
\hline & Year 12 or below & 57.7 & 52.9 & 55.1 \\
\hline Disability/long-term health condition & & 29.4 & 24.6 & 26.8 \\
\hline \multirow{2}{*}{$\begin{array}{l}\text { Labour market history (\% of time } \\
\text { since left full-time education) }\end{array}$} & Time in paid work & 50.7 & $64.1^{* *}$ & 57.9 \\
\hline & Time unemployed & 23.2 & $17.5^{* *}$ & 20.1 \\
\hline Employment rate ${ }^{\mathrm{c}}$ & & 28.4 & $49.7 * *$ & 40.1 \\
\hline $\begin{array}{l}\text { Mean weekly wage of the employed } \\
\text { (\$) }\end{array}$ & & 357 & $545^{* *}$ & 180 \\
\hline
\end{tabular}

Source: Confidentialised unit records from the HILDA Survey waves 1-6 Release 6.0

a. Main English Speaking countries are New Zealand, United Kingdom (UK), Ireland, Canada, US and South Africa.

b. The regions are classified by remoteness area where each remoteness area represents an aggregation of non-contiguous geographical areas which share common characteristics of remoteness based on the Accessibility/Remoteness Index of Australia (ARIA). Major cities are collection districts with an ARIA index of 0 to 0.2 and inner regions are collection districts with an average ARIA index greater than 0.2 but less than or equal to 2.4. For further details, refer to Australian Bureau of Statistics (2001).

c. In each year, the HILDA survey respondents are asked whether they have enrolled in a LMP since the last financial year and what their employment status is at the time of the interview. For example, a survey respondent who was interviewed in August 2001 would report LMP status based on whether s/he was enrolled in a LMP between July 2000 and August 2001, but employment status would be reported by the respondent based on his/her employment status in August 2001. Hence, if a respondent enrolled in a LMP in the last financial year became employed by the time of the interview, that respondent would be recorded as employed in the year when first enrolled in a LMP.

** Statistically significantly different from HA participants at $1 \%$ level

* Statistically significantly different from HA participants at 5\% level 
Table 2: Changes in the composition of HA and non-HA groups, per cent unless stated otherwise

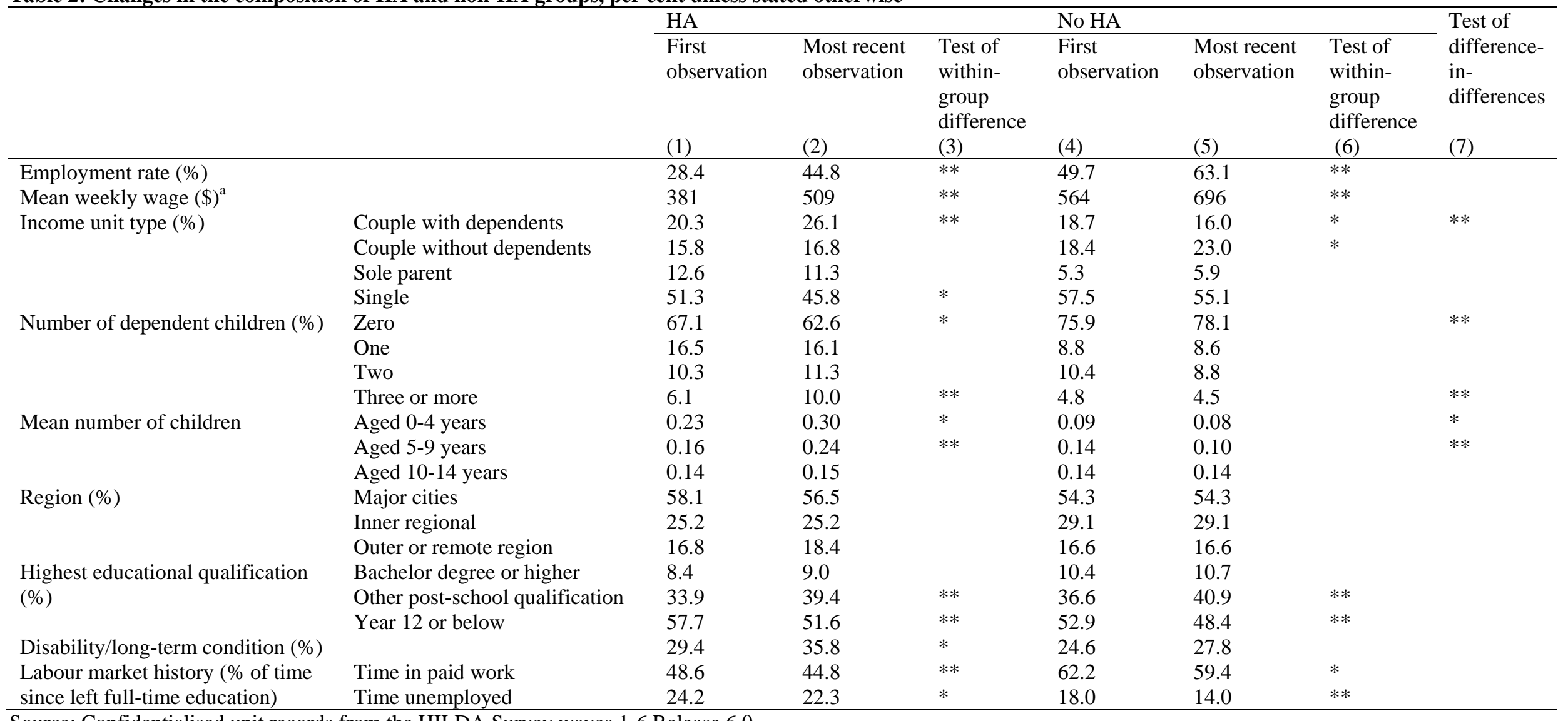

Source: Confidentialised unit records from the HILDA Survey waves 1-6 Release 6.0

Notes:

a. Mean weekly wage in this table has been measured with respect to sample members who were employed both during the first and last observation. In the HA group, there are 48 such persons; in the non-HA group there are 154 such persons.

** Test statistic is significant at $1 \%$ level; * Test statistic is significant at $5 \%$ level 
Table 3: Random effects and IV model estimates

\begin{tabular}{|c|c|c|c|c|c|c|}
\hline \multirow[t]{2}{*}{ Explanatory variable } & \multicolumn{2}{|c|}{ Random Effects } & \multicolumn{3}{|c|}{ IV model } & \multirow[b]{2}{*}{$\begin{array}{l}\text { Marg. } \\
\text { effect }\end{array}$} \\
\hline & $\begin{array}{r}\text { Coef. } \\
\text { (standard } \\
\text { errors }\end{array}$ & & $\begin{array}{l}\text { Marg. } \\
\text { effect }\end{array}$ & $\begin{array}{r}\text { Coef. } \\
\text { (standard } \\
\text { errors) }\end{array}$ & & \\
\hline $\begin{array}{l}\text { Whether received HA at some point during } \\
\text { waves } 1-6\left(H_{i}\right)\end{array}$ & $\begin{array}{r}-0.984 \\
(0.289)\end{array}$ & $* *$ & -0.224 & & & \\
\hline $\begin{array}{l}\text { Proportion of waves in receipt of HA ( } \bar{H}_{i} \text {, in per } \\
\text { cent) }\end{array}$ & & & & $\begin{array}{r}-0.018 \\
(0.005)\end{array}$ & $* *$ & -0.004 \\
\hline Whether received HA during wave $t-1\left(H_{i t-1}\right)$ & & & & $\begin{array}{r}0.510 \\
(0.344)\end{array}$ & & 0.115 \\
\hline \multicolumn{7}{|l|}{ LMP category (Employment assistance default) } \\
\hline Employment and community participation & $\begin{array}{r}-1.226 \\
(0.316)\end{array}$ & $* *$ & -0.292 & $\begin{array}{l}-1.210 \\
(0.316)\end{array}$ & $* *$ & -0.288 \\
\hline Training & $\begin{array}{r}-0.407 \\
(0.426)\end{array}$ & & -0.097 & $\begin{array}{l}-0.405 \\
(0.425)\end{array}$ & & -0.097 \\
\hline \multicolumn{7}{|l|}{ Year (2002 default) ${ }^{a}$} \\
\hline 2003 & $\begin{array}{r}0.577 \\
(0.299)\end{array}$ & $*$ & 0.124 & $\begin{array}{r}0.586 \\
(0.300)\end{array}$ & $*$ & 0.126 \\
\hline 2004 & $\begin{array}{r}1.379 \\
(0.308)\end{array}$ & $* *$ & 0.269 & $\begin{array}{r}1.407 \\
(0.310)\end{array}$ & $* *$ & 0.273 \\
\hline 2005 & $\begin{array}{r}1.336 \\
(0.306)\end{array}$ & $* *$ & 0.265 & $\begin{array}{r}1.383 \\
(0.309)\end{array}$ & $* *$ & 0.273 \\
\hline 2006 & $\begin{array}{r}1.551 \\
(0.306)\end{array}$ & $* *$ & 0.307 & $\begin{array}{r}1.599 \\
(0.309)\end{array}$ & $* *$ & 0.315 \\
\hline \multicolumn{7}{|l|}{ Personal characteristics } \\
\hline Age & $\begin{array}{r}0.208 \\
(0.075)\end{array}$ & $* *$ & 0.0479 & $\begin{array}{r}0.196 \\
(0.074)\end{array}$ & $* *$ & 0.045 \\
\hline Age squared & $\begin{array}{r}-0.004 \\
(0.001)\end{array}$ & ** & -0.001 & $\begin{array}{r}-0.004 \\
(0.001)\end{array}$ & $* *$ & -0.001 \\
\hline Female & $\begin{array}{r}-0.010 \\
(0.296)\end{array}$ & & -0.002 & $\begin{array}{r}-0.034 \\
(0.294)\end{array}$ & & -0.008 \\
\hline Disabled & $\begin{array}{r}-1.272 \\
(0.226)\end{array}$ & $* *$ & -0.299 & $\begin{array}{r}-1.241 \\
(0.226)\end{array}$ & $* *$ & -0.291 \\
\hline \multicolumn{7}{|l|}{ Income unit type (Single default) } \\
\hline Couple with dependent children & $\begin{array}{r}-0.443 \\
(0.479)\end{array}$ & & -0.105 & $\begin{array}{r}-0.340 \\
(0.480)\end{array}$ & & -0.080 \\
\hline Couple without dependent children & $\begin{array}{r}0.206 \\
(0.305)\end{array}$ & & 0.047 & $\begin{array}{r}0.175 \\
(0.305)\end{array}$ & & 0.040 \\
\hline Sole parent & $\begin{array}{r}-0.434 \\
(0.554)\end{array}$ & & -0.104 & $\begin{array}{r}-0.312 \\
(0.555)\end{array}$ & & -0.074 \\
\hline \multicolumn{7}{|l|}{ Number of children } \\
\hline Number of children aged $0-4$ years & $\begin{array}{r}-0.514 \\
(0.289)\end{array}$ & & -0.118 & $\begin{array}{r}-0.498 \\
(0.290)\end{array}$ & & -0.115 \\
\hline Number of children aged 5-9 years & $\begin{array}{r}0.095 \\
(0.295)\end{array}$ & & 0.022 & $\begin{array}{r}0.107 \\
(0.296)\end{array}$ & & 0.025 \\
\hline Number of children aged 10-14 years & $\begin{array}{r}-0.020 \\
(0.317)\end{array}$ & & -0.005 & $\begin{array}{r}0.003 \\
(0.318)\end{array}$ & & 0.001 \\
\hline \multicolumn{7}{|l|}{ Ethnicity (Australian non-Indigenous default) } \\
\hline Australian Indigenous & $\begin{array}{r}-0.595 \\
(0.638)\end{array}$ & & -0.144 & $\begin{array}{r}-0.470 \\
(0.640)\end{array}$ & & -0.113 \\
\hline Main English-speaking countries ${ }^{\mathrm{b}}$ & $\begin{array}{r}0.050 \\
(0.486)\end{array}$ & & 0.012 & $\begin{array}{r}0.110 \\
(0.487)\end{array}$ & & 0.025 \\
\hline Other & $\begin{array}{r}-0.284 \\
(0.409)\end{array}$ & & -0.067 & $\begin{array}{r}-0.291 \\
(0.408)\end{array}$ & & -0.069 \\
\hline \multicolumn{7}{|l|}{ Region (Major city default) } \\
\hline Inner region & $\begin{array}{r}-0.856 \\
(0.319)\end{array}$ & $* *$ & -0.204 & $\begin{array}{r}-0.938 \\
(0.320)\end{array}$ & $* *$ & -0.224 \\
\hline Outer region & $\begin{array}{r}-0.455 \\
(0.352)\end{array}$ & & -0.108 & $\begin{array}{r}-0.538 \\
(0.354)\end{array}$ & & -0.128 \\
\hline
\end{tabular}

Highest qualification (no post-school qualification default) 


\begin{tabular}{|c|c|c|c|c|c|c|}
\hline \multirow[t]{2}{*}{ Explanatory variable } & \multicolumn{2}{|c|}{ Random Effects } & \multicolumn{3}{|c|}{ IV model } & \multirow[b]{2}{*}{$\begin{array}{l}\text { Marg. } \\
\text { effect }\end{array}$} \\
\hline & $\begin{array}{r}\text { Coef. } \\
\text { (standard } \\
\text { errors }\end{array}$ & & $\begin{array}{l}\text { Marg. } \\
\text { effect }\end{array}$ & $\begin{array}{r}\text { Coef. } \\
\text { (standard } \\
\text { errors) } \\
\end{array}$ & & \\
\hline Bachelor degree or higher & $\begin{aligned}-0.166 \\
(0.480)\end{aligned}$ & & -0.039 & $\begin{array}{r}-0.128 \\
(0.480)\end{array}$ & & -0.030 \\
\hline Other post-school qualification & $\begin{array}{r}0.265 \\
(0.290)\end{array}$ & & 0.060 & $\begin{array}{r}0.249 \\
(0.290)\end{array}$ & & 0.057 \\
\hline Labour market history & & & & & & \\
\hline $\begin{array}{l}\text { Time in paid work as a proportion of time since } \\
\text { left full-time education }\end{array}$ & $\begin{array}{r}0.028 \\
(0.005)\end{array}$ & ** & 0.006 & $\begin{array}{r}0.027 \\
(0.005)\end{array}$ & $* *$ & 0.006 \\
\hline $\begin{array}{l}\text { Time unemployed as a proportion of time since } \\
\text { left full-time education }\end{array}$ & $\begin{array}{r}-0.021 \\
(0.007)\end{array}$ & ** & -0.005 & $\begin{array}{r}-0.019 \\
(0.007)\end{array}$ & $* *$ & -0.004 \\
\hline Constant & $\begin{array}{r}-1.805 \\
(1.414)\end{array}$ & & & $\begin{array}{r}-1.699 \\
(1.410)\end{array}$ & & \\
\hline$\psi^{2 \mathrm{c}}$ & $\begin{array}{r}2.120 \\
(0.209)\end{array}$ & ** & & $\begin{array}{r}2.113 \\
(0.209)\end{array}$ & $* *$ & \\
\hline$\rho^{c}$ & $\begin{array}{r}0.577 \\
(0.048)\end{array}$ & ** & & $\begin{array}{r}0.576 \\
(0.048)\end{array}$ & & \\
\hline Diagnostics & & & & & & \\
\hline Number of observations & 1450 & & & 1450 & & \\
\hline Number of groups & 527 & & & 527 & & \\
\hline Wald $\mathrm{Chi}^{2}$ & 148.23 & ** & & 149.25 & $* *$ & \\
\hline Likelihood ratio test of $\rho=0$ & 157.18 & $* *$ & & 154.56 & $* *$ & \\
\hline
\end{tabular}

Source: Confidentialised unit records from the HILDA Survey waves 1-6 Release 6.0

Notes:

a. All wave 1 observations are excluded due to the lagging of the housing assistance variables, leaving observations from wave 2 (2002) onwards for analysis.

b. Main English Speaking countries are New Zealand, United Kingdom (UK), Ireland, Canada, US and South Africa.

c. $\psi^{2}$ is the variance of the between-individual error term. $\rho$ is the proportion of the total variance contributed by the variance of the between-individual error term.

** Significant at the $1 \%$ level * Significant at the $5 \%$ level 
Table 4: IV model estimates for disaggregated HA status

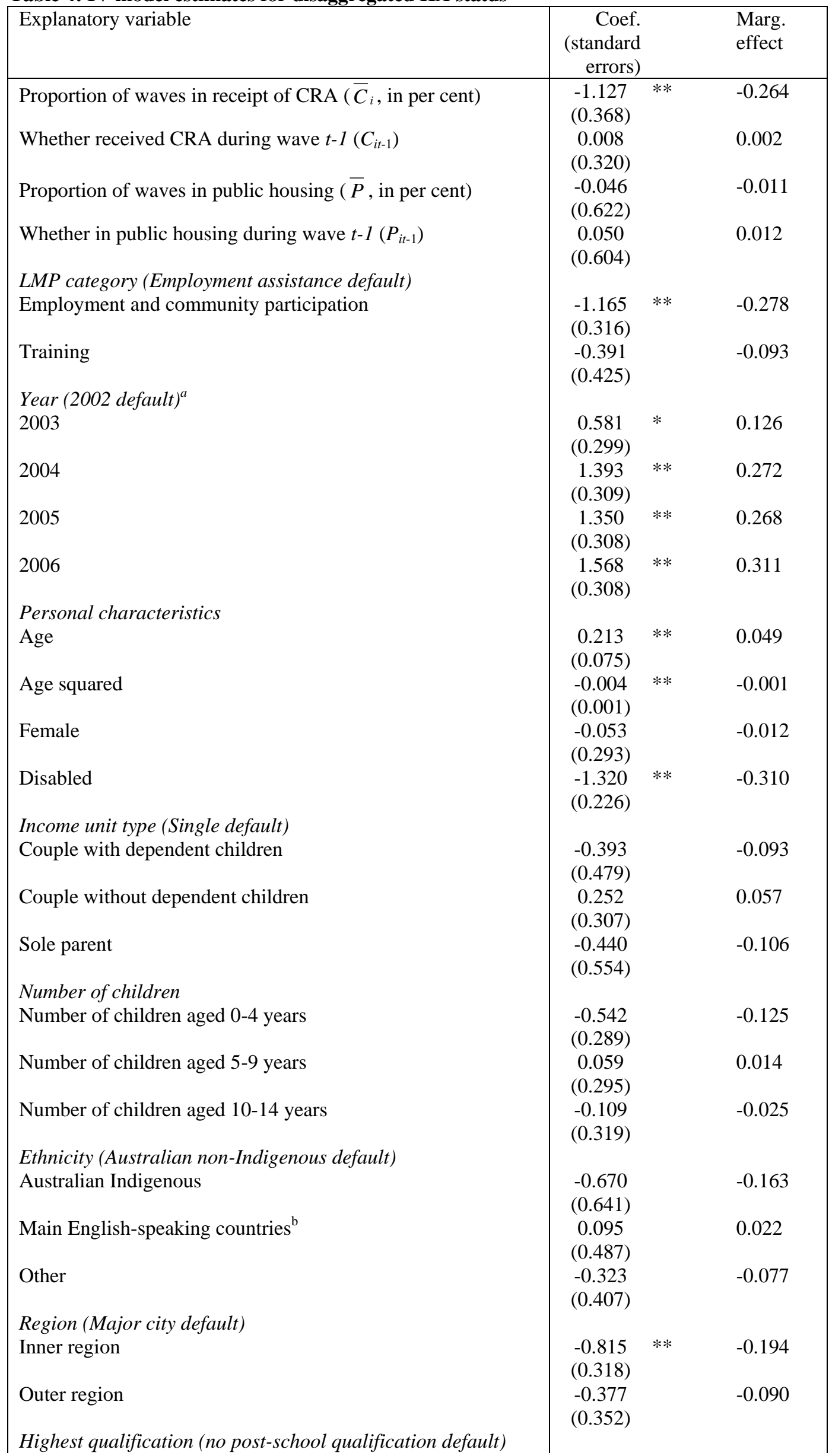




\begin{tabular}{|c|c|c|c|}
\hline Explanatory variable & $\begin{array}{r}\text { Coef. } \\
\text { (standard } \\
\text { errors) } \\
\end{array}$ & & $\begin{array}{l}\text { Marg. } \\
\text { effect }\end{array}$ \\
\hline Bachelor degree or higher & $\begin{array}{l}-0.155 \\
(0.478)\end{array}$ & & -0.036 \\
\hline Other post-school qualification & $\begin{array}{c}0.236 \\
(0.290)\end{array}$ & & 0.054 \\
\hline Labour market history & & & \\
\hline $\begin{array}{l}\text { Time in paid work as a proportion of time since left full-time } \\
\text { education }\end{array}$ & $\begin{array}{c}0.028 \\
(0.005)\end{array}$ & $* *$ & 0.006 \\
\hline $\begin{array}{l}\text { Time unemployed as a proportion of time since left full-time } \\
\text { education }\end{array}$ & $\begin{array}{l}-0.022 \\
(0.007)\end{array}$ & $* *$ & -0.005 \\
\hline Constant & $\begin{array}{l}-1.906 \\
(1.410)\end{array}$ & & \\
\hline$\psi^{2 c}$ & $\begin{array}{l}2.105 \\
(0.209)\end{array}$ & $* *$ & \\
\hline$\rho^{c}$ & $\begin{array}{c}0.574 \\
(0.049)\end{array}$ & $* *$ & \\
\hline Diagnostics & & & \\
\hline Number of observations & 1450 & & \\
\hline Number of groups & 527 & & \\
\hline Wald $\mathrm{Chi}^{2}$ & 150.24 & $* *$ & \\
\hline Likelihood ratio test of $\rho=0$ & 152.41 & $* *$ & \\
\hline
\end{tabular}

\section{Notes:}

a. All wave 1 observations are excluded due to the lagging of the housing assistance variables, leaving observations from wave 2 (2002) onwards for analysis.

b. Main English Speaking countries are New Zealand, United Kingdom (UK), Ireland, Canada, US and South Africa.

c. $\psi^{2}$ is the variance of the between-individual error term. $\rho$ is the proportion of the total variance contributed by the variance of the between-individual error term.

** Significant at the $1 \%$ level * Significant at the $5 \%$ level 
Table A1: Definitions of variables

\begin{tabular}{|c|c|c|c|}
\hline Variables & $\begin{array}{l}\text { Binary/Conti } \\
\text { nuous }\end{array}$ & $\begin{array}{l}\text { Time-invariant } \\
\text { or time-varying }\end{array}$ & Definitions \\
\hline $\begin{array}{l}\text { Dependent variable - } \\
\text { whether employed } \\
\text { HA status }\end{array}$ & Binary & Time-varying & $\begin{array}{l}1 \text { if a person is working one or more hours } \\
\text { per week; } 0 \text { otherwise }\end{array}$ \\
\hline $\begin{array}{l}\text { Whether received } \mathrm{HA} \text { at } \\
\text { some point during timeframe } \\
\left(\mathrm{H}_{i}\right)\end{array}$ & Binary & Time-invariant & $\begin{array}{l}1 \text { if received HA at some point during waves } \\
1-6 ; 0 \text { otherwise }\end{array}$ \\
\hline $\begin{array}{l}\text { Proportion of waves in } \\
\text { receipt of HA }\left(\bar{H}_{i}\right)\end{array}$ & Continuous & Time-invariant & $\begin{array}{l}\text { Number of waves in receipt of HA } \\
\text { expressed as a percentage of total number of } \\
\text { waves observed during timeframe }\end{array}$ \\
\hline $\begin{array}{l}\text { Whether received HA during } \\
\text { wave } t-1\left(H_{i t-1}\right)\end{array}$ & Binary & Time-varying & 1 if received HA in wave $t-1 ; 0$ otherwise \\
\hline $\begin{array}{l}\text { Proportion of waves in } \\
\text { receipt of CRA ( } \bar{C}_{i} \text {, in per } \\
\text { cent) }\end{array}$ & Binary & Time-invariant & $\begin{array}{l}\text { Number of waves in receipt of CRA } \\
\text { expressed as a percentage of total number of } \\
\text { waves observed during timeframe }\end{array}$ \\
\hline $\begin{array}{l}\text { Whether received CRA } \\
\text { during wave } t-1\left(C_{i t-1}\right)\end{array}$ & Binary & Time-varying & 1 if received CRA in wave $t-1 ; 0$ otherwise \\
\hline $\begin{array}{l}\text { Proportion of waves in } \\
\text { public housing ( } \bar{P} \text {, in per } \\
\text { cent) }\end{array}$ & Binary & Time-invariant & $\begin{array}{l}\text { Number of waves in public housing } \\
\text { expressed as a percentage of total number of } \\
\text { waves observed during timeframe }\end{array}$ \\
\hline $\begin{array}{l}\text { Whether in public housing } \\
\text { during wave } t-1\left(P_{i t-1}\right) \\
\text { LMP category }\end{array}$ & Binary & Time-varying & $\begin{array}{l}1 \text { if in public housing in wave } t-1 ; 0 \\
\text { otherwise }\end{array}$ \\
\hline $\begin{array}{l}\text { Employment assistance } \\
\text { (default) }\end{array}$ & Binary & Time-invariant & $\begin{array}{l}1 \text { if participated in a one-to-one programme } \\
\text { that helps prepare unemployed persons for } \\
\text { work opportunities by guiding job search, } \\
\text { helping with the preparation of resumes and } \\
\text { so on; } 0 \text { otherwise }\end{array}$ \\
\hline $\begin{array}{l}\text { Employment and community } \\
\text { participation }\end{array}$ & Binary & Time-invariant & $\begin{array}{l}1 \text { if participated in activities such as Work } \\
\text { for the Dole, community work or any form } \\
\text { of paid part-time employment during } \\
\text { timeframe; } 0 \text { otherwise }\end{array}$ \\
\hline Training & Binary & Time-invariant & $\begin{array}{l}1 \text { if participated in training programmes } \\
\text { such as defence force reserve or approved } \\
\text { language, literacy and numeracy schooling; } \\
0 \text { otherwise }\end{array}$ \\
\hline \multicolumn{4}{|r|}{ 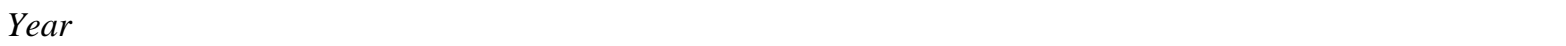 } \\
\hline 2002 (default) & Binary & Time-varying & $\begin{array}{l}1 \text { if observation is from the } 2002 \text { calendar } \\
\text { year; } 0 \text { otherwise }\end{array}$ \\
\hline 2003 & Binary & Time-varying & $\begin{array}{l}1 \text { if observation is from the } 2003 \text { calendar } \\
\text { year; } 0 \text { otherwise }\end{array}$ \\
\hline 2004 & Binary & Time-varying & $\begin{array}{l}1 \text { if observation is from the } 2004 \text { calendar } \\
\text { year; } 0 \text { otherwise }\end{array}$ \\
\hline 2005 & Binary & Time-varying & $\begin{array}{l}1 \text { if observation is from the } 2005 \text { calendar } \\
\text { year; } 0 \text { otherwise }\end{array}$ \\
\hline 2006 & Binary & Time-varying & $\begin{array}{l}1 \text { if observation is from the } 2006 \text { calendar } \\
\text { year; } 0 \text { otherwise }\end{array}$ \\
\hline \multicolumn{4}{|l|}{ Personal characteristics } \\
\hline Age & Continuous & Time-varying & Age in years \\
\hline Age squared & Continuous & Time-varying & Age $x$ age \\
\hline Female & Binary & Time-invariant & 1 if female; 0 otherwise \\
\hline Disabled & Binary & Time-varying & $\begin{array}{l}1 \text { if have a disability or long-term health } \\
\text { condition; } 0 \text { otherwise }\end{array}$ \\
\hline \multicolumn{4}{|l|}{ Income unit type } \\
\hline $\begin{array}{l}\text { Couple with dependent } \\
\text { children }\end{array}$ & Binary & Time-varying & $\begin{array}{l}1 \text { if partnered and have dependent children; } \\
0 \text { otherwise }\end{array}$ \\
\hline $\begin{array}{l}\text { Couple without dependent } \\
\text { children }\end{array}$ & Binary & Time-varying & $\begin{array}{l}1 \text { if partnered and have no dependent } \\
\text { children; } 0 \text { otherwise }\end{array}$ \\
\hline Sole parent & Binary & Time-varying & 1 if single with dependent children; 0 \\
\hline
\end{tabular}




\begin{tabular}{|c|c|c|c|}
\hline Variables & $\begin{array}{l}\text { Binary/Conti } \\
\text { nuous }\end{array}$ & $\begin{array}{l}\text { Time-invariant } \\
\text { or time-varying }\end{array}$ & Definitions \\
\hline Single (default) & Binary & Time-varying & $\begin{array}{l}\text { otherwise } \\
1 \text { if single without dependent children; } 0 \\
\text { otherwise }\end{array}$ \\
\hline \multicolumn{4}{|l|}{ Number of children } \\
\hline $\begin{array}{l}\text { Number of children aged 0-4 } \\
\text { years }\end{array}$ & Continuous & Time-varying & \\
\hline $\begin{array}{l}\text { Number of children aged 5-9 } \\
\text { years }\end{array}$ & Continuous & Time-varying & \\
\hline $\begin{array}{l}\text { Number of children aged } 10- \\
14 \text { years }\end{array}$ & Continuous & Time-varying & \\
\hline \multicolumn{4}{|l|}{ Ethnicity } \\
\hline $\begin{array}{l}\text { Australian non-Indigenous } \\
\text { (default) }\end{array}$ & Binary & Time-invariant & $\begin{array}{l}1 \text { if born in Australia and not an Aboriginal } \\
\text { or Torres Strait Islander; } 0 \text { otherwise }\end{array}$ \\
\hline Australian Indigenous & Binary & Time-invariant & $\begin{array}{l}1 \text { if born in Australia and an Aboriginal or } \\
\text { Torres Strait Islander; } 0 \text { otherwise }\end{array}$ \\
\hline $\begin{array}{l}\text { Main English-speaking } \\
\text { countries }\end{array}$ & Binary & Time-invariant & $\begin{array}{l}1 \text { if born in New Zealand, United Kingdom } \\
\text { (UK), Ireland, Canada, US or South Africa; } \\
0 \text { otherwise }\end{array}$ \\
\hline Other & Binary & Time-invariant & $\begin{array}{l}1 \text { if born outside Australia and the main } \\
\text { English-speaking countries listed above; } 0 \\
\text { otherwise }\end{array}$ \\
\hline \multicolumn{4}{|r|}{ 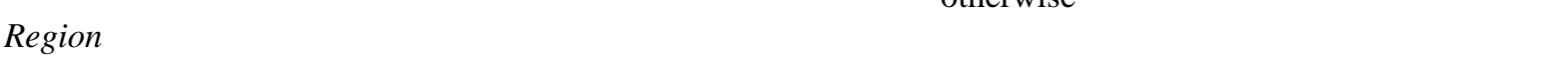 } \\
\hline Major city (default) & Binary & Time-varying & $\begin{array}{l}1 \text { if residing in a collection district with an } \\
\text { Accessibility/Remoteness Index of Australia } \\
\text { (ARIA) index of } 0 \text { to } 0.2 ; 0 \text { otherwise }\end{array}$ \\
\hline Inner region & Binary & Time-varying & $\begin{array}{l}1 \text { if residing in a collection district with an } \\
\text { average ARIA index greater than } 0.2 \text { and } \\
\text { less than or equal to } 2.4 ; 0 \text { otherwise }\end{array}$ \\
\hline Outer region & Binary & Time-varying & $\begin{array}{l}1 \text { if residing in a collection district with an } \\
\text { average ARIA index greater than 2.4; } 0 \\
\text { otherwise }\end{array}$ \\
\hline \multicolumn{4}{|l|}{ Highest qualification } \\
\hline Bachelor degree or higher & Binary & Time-varying & $\begin{array}{l}1 \text { if highest qualification is a bachelor degree } \\
\text { or higher; } 0 \text { otherwise }\end{array}$ \\
\hline $\begin{array}{l}\text { Other post-school } \\
\text { qualification }\end{array}$ & Binary & Time-varying & $\begin{array}{l}1 \text { if highest qualification is a post-school } \\
\text { qualification that is not a bachelor degree or } \\
\text { higher; } 0 \text { otherwise }\end{array}$ \\
\hline $\begin{array}{l}\text { No post-school qualification } \\
\text { (default) } \\
\text { Labour market history }\end{array}$ & Binary & Time-varying & $\begin{array}{l}1 \text { if highest qualification is Year } 12 \text { or } \\
\text { lower; } 0 \text { otherwise }\end{array}$ \\
\hline $\begin{array}{l}\text { Time in paid work as a } \\
\text { proportion of time since left } \\
\text { full-time education }\end{array}$ & Continuous & Time-varying & $\begin{array}{l}\text { Time in paid work expressed as a percentage } \\
\text { of time since left full-time education }\end{array}$ \\
\hline $\begin{array}{l}\text { Time unemployed as a } \\
\text { proportion of time since left } \\
\text { full-time education }\end{array}$ & Continuous & Time-varying & $\begin{array}{l}\text { Time unemployed expressed as a percentage } \\
\text { of time since left full-time education }\end{array}$ \\
\hline
\end{tabular}




\section{References}

Australian Bureau of Statistics (2001), Statistical Geography Volume 1 Australian Standard Geographical Classification (ASGC) 2001, Cat. No. 1216.0, Australian Bureau of Statistics, Canberra.

Australian Bureau of Statistics (2009), Labour Force, Australia, Spreadsheets, Jan 2009, Cat. No. 6202.0.55.001, Australian Bureau of Statistics, Canberra.

Baxter, J., Hewitt, B. and Haynes, M. (2008), 'Life Course Transitions and Housework: Marriage, Parenthood, and Time on Housework', Journal of Marriage and Family, 70(2), 259-272.

Blank, R.M. (2002), 'Evaluating Welfare Reform in the United States', Journal of Economic Literature, 40(4), pp. 1105-1166.

Brennan, A., Rhodes, J. And Tyler, P. (2000), 'The Nature of Local Area Social Exclusion in England and the Role of the Labour Market', Oxford Review of Economic Policy, 16(1): 129-146.

Burgess, J., Mitchell, W.F., O’Brien, D.J. and Watts, M.J. (2000), 'The Developing Workfare Policy in Australia: A Critical Assessment', Journal of Socio-Economics, 29, 173-188.

Centrelink (2008), Options for Your Future-Mutual Obligation Factsheet, Centrelink Facts Publication, Australian Government, Canberra.

Corcoran, M. and Heflin, C. (2003), 'Barriers to Work Among Recipients of Housing Assistance', Cityscape: A Journal of Policy Development and Research, 6(2), pp. 73-87.

Council of Australian Governments (2009), National Affordable Housing Agreement, Available: http://www.coag.gov.au/intergov_agreements/federal_financial_relations/index.cfm

Curtain, R. (2000), Mutual Obligation and the Young Unemployed: Policy and Practice in Australia compared with the UK, Paper presented at the Australian Academy of Social Sciences Workshop on Mutual Obligations and Welfare States in Transition in Australia, the US and the UK, February 22-23, Sydney.

Dickens, R., Gregg, P. And Wadsworth, J. (2000), 'New Labour and the Labour Market', Oxford Review of Economic Policy, 16(1): 95-113.

Dockery, A.M., Flatau, P., Ong, R. and Wood, G. (2008a, forthcoming), 'An Analysis of the Impact of Tax and Welfare Reform Measures on Effective Marginal Tax Rates in Australia, 19822002', Australian Journal of Labour Economics, 11(3).

Dockery A.M., Ong R., Whelan S. \& Wood G.A. (2008b) The Relationship between Public Housing Wait Lists, Public Housing Tenure and Labour Market Outcomes, National Research Venture 1: Housing Assistance and Economic Participation, Research Paper 9, Australian Housing and Urban Research Institute. Available: http://www.ahuri.edu.au/nrv/nrv1/NRV1_docs.html

Fletcher, D.R., Gore, T., Reeve, K. and Robinson, D. (2008), Social Housing and Worklessness: Key Policy Messages, Research Report No. 482, Published for the Department for Work and Pensions under licence from the Controller of Her Majesty's Stationery Office, Norwich, Available: http://research.dwp.gov.uk/asd/asd5/rports2007-2008/rrep482.pdf

Friedman, D.H., Meschede, T. and Hayes, M. (2003), 'Surviving Against the Odds: Families Journeys off Welfare and out of Homelessness', Cityscape: A Journal of Policy Development and Research, 6(2), pp. 187-206.

Harkness, J.M. and Newman, S.J. (2006), 'Recipients of Housing Assistance under Welfare Reform: Trends in Employment and Welfare Participation, Housing Policy Debate, 17(1), pp. 81-108.

Lee, W, Beecroft, E. Khadduri, J. and Patterson, R. (2003), Impacts of Welfare Reform on Housing Assistance Recipients: Evidence from Indiana and Delaware, US Department of Housing and Urban Development, Office of Policy Development and Research, Washington DC. 
Lim, H.H.F. (2008), The Impact of Mutual Obligation on Mature Age NewStart Allowance Recipients: A Program Evaluation, Discussion Paper No. 65, National Centre for Social and Economic Modelling, University of Canberra.

McQuaid, R.W. and Greig, M. (2004), 'Are New Deal Employment Initiatives on Target?', International Journal of Manpower, 25(5), 392-410.

Meyer, B. D. (1995), 'Natural and Quasi-Experiments in Economics', Journal of Business and Economic Statistics, 13(2), pp. 151-161.

MIAESR (Melbourne Institute of Applied and Economic Social Research) (2001a), Living in Australia: Introduction and Showcard Set, MIAESR, Melbourne.

MIAESR (Melbourne Institute of Applied and Economic Social Research) (2001b), Person Questionnaire, MIAESR, Melbourne.

Miller, C. (1998), Explaining the Minnesota Family Investment Program's Impacts by Housing Status, Manpower Demonstration Research Corporation, New York.

Miller, C., Knox, P., Auspos, J., Hunter-Manns, J. and Orenstein, A. (1997), Making Welfare Work and Work Pay: Implementation and 18-Month Impacts of the Family Investment Program, Manpower Demonstration Research Corporation, New York.

Mundlak, Y. (1978), 'On the Pooling of Time Series and Cross-sectional Data', Econometrica, 46, 69-86.

Murray, M. P. (1980) A Reinterpretation of the Traditional Income-Leisure Model, With Application To In-Kind Subsidy Programs, Journal of Public Economics, Vol. 14, 69-81.

Nagle, G. (2003), 'Comparing Housing-Assisted and Housing-Unassisted Welfare Leavers in Massachusetts', Cityscape: A Journal of Policy Development and Research, 6(2), pp.139158.

Riccio, J.A. and Orenstein, A. (2001) Are Welfare Recipients in Public Housing Really Harder to Employ?, Manpower Demonstration Research Corporation, New York.

Richardson, L. (2002), 'Impact of the Mutual Obligation Initiative on the Exit Behaviour of Unemployment Benefit Recipients: The Threat of Additional Activities', The Economic Record, 78(243), pp. 406-421.

Schone, B. S. (1992) Do Means Tested Transfers Reduce Labour Supply? Economic Letters, Vol. 4: 353-358

Skrondal, A. and Rabe-Hesketh, S. (2004), Generalized Latent Variable Modeling: Multilevel, Longitudinal, and Structural Equation Models, Chapman and Hall/CRC Press, Boca Raton, Florida.

Steering Committee for the Review of Government Service Provision (2007), Report on Government Services 2007, Productivity Commission, Melbourne.

Susin, S. (2005), 'Longitudinal Outcomes of Subsidized Housing Recipients in Matched Survey and Administrative Data', Cityscape: A Journal of Policy Development and Research, 8(2), pp. 95-114.

Treasurer (2002), Budget Speech 2001-02, Available: http://www.budget.gov.au/200102/speech/download/speech.pdf

Van Ryzin, G.G., Kaestner, R., and Main, T.J. (2003), 'The Effects of Federal and Local Housing Programs on the Transition from Welfare to Work: Evidence from New York City', Cityscape: A Journal of Policy Development and Research, 6(2), pp. 45-72.

Verma, N and Hendra, R. (2003), 'Comparing Outcomes for Los Angeles County's HUD-Assisted and Unassisted Welfare Leavers', Cityscape: A Journal of Policy Development and Research, 6(2), pp. 89-122.

Verma, N., Riccio, J.A. and Azurdia, G.L. (2003), Housing Assistance and the Effects of Welfare Reform: Evidence from Connecticut and Minnesota, Report prepared for the US Department of Housing and Urban Development Office of Policy Development and Research, Washington DC.

Wadsworth, J. (1998), Eyes Down for a Full House: Labour Market Polarisation and the Housing Market in Britain, Scottish Journal of Political Economy, Vol. 45, No. 4: 376-392. 
Wood, G. A., Forbes, M. and Gibb, K. D. (2005), Direct Subsidies and Housing Affordability in Australian Private Rental Markets, Environment and Planning C: Government and Policy, Vol. 23: 759-783.Wood, G.A., Ong, R. Dockery, A.M. and Flatau, P. (2005), Housing Assistance Programmes and Their Contribution to Poverty and Unemployment Traps, National Research Venture 1: Housing Assistance and Economic Participation, Research Paper 1, Australian Housing and Urban Research Institute, Available: http://www.ahuri.edu.au/nrv/nrv1/NRV1_docs.html

Wood, G.A. and Ong, R. (2008), Redesigning AHURI's Australian Housing Market Microsimulation Model. Report. November. Melbourne: Australian Housing and Urban Research Institute.

Wood, G.A., Ong, R. and Dockery, A. M. (2009), 'The Long-run Decline in Employment Participation for Australian Public Housing Tenants: An Investigation', Housing Studies, 24(1), 103-126.

Yeend, P. (2004), Mutual Obligation/Work for the Dole, Available: http://www.aph.gov.au/library/INTGUIDE/sp/dole.htm

\title{
Footnotes
}

\begin{abstract}
${ }^{\mathrm{i}}$ The authors wish to acknowledge the helpful comments from five anaonymous referees. The paper uses unit record data from the Household, Income and Labour Dynamics in Australia (HILDA) Survey. The HILDA Project was initiated and is funded by the Australian Government Department of Families, Housing, Community Services and Indigenous Affairs (FaHCSIA) and is managed by the Melbourne Institute of Applied and Economic and Social Research (MIAESR). The findings and views reported in this paper are those of the authors and should not be attributed to FaHCSIA, MIAESR or the referees.
\end{abstract}

ii While New Deal programmes for unemployment benefit recipients are compulsory, there are also non-compulsory New Deal programmes available for other benefit recipients such as lone parents and people with disabilities, designed to support job search for those who wish to enroll in the programmes (Dickens et al 2000).

iii Murray (1980) and Schone (1992) demonstrate in a formal choice theoretic framework that commodity subsidy programmes such as HA can cause labour supply to increase if the subsidized commodity and work are complements. This outcome is more likely if the subsidized commodity is rationed and offered in fixed quantities that exceed the quantity that would be consumed with an equivalent cash transfer.

${ }^{\text {iv }}$ Declining employment participation among males in public housing is a notable trend in the UK as well (Dickens et al., 2000; Wadsworth, 1998).

${ }^{\mathrm{v}}$ CRA is paid at the rate of 75 cents per dollar of rent above the specified minimum rent threshold until the maximum rate is reached. These thresholds vary according to household size and type of income support program (Wood, Forbes and Gibb, 2005).

${ }^{\text {vi }}$ Our definition of HA includes direct subsides but excludes indirect subsidies, in particular tax expenditures. While mortgage interest is not tax deductible in Australia, capital gains and net imputed rents are tax exempt. There has been speculation that this depresses the labour supply of mature age workers. But further exploration is outside the scope of this paper.

vii Those enrolled in 2001 could have begun their program in an earlier year; those that record first participation in 2002 or later have begun their program in that year.

viii Unemployed respondents in the HILDA Survey are presented with a showcard listing the following LMPs and asked “... since (the last financial year), have you been required by Centrelink or a Job Network provider to do any of the following?”: Part-time study, part-time paid work, voluntary unpaid work, community work organised by a community work coordinator, Work for the Dole, job search training (training to search for jobs, write applications and prepare for interviews), approved literacy/numeracy training, Green Corps, Job Placement Employment and Training (JPET), Intensive Assistance (one-to-one help to plan your return to work and find and keep a job), Community Development Employment Projects, relocating to an area of better employment prospects, New Apprenticeship Access Program (training to get you into a new apprenticeship), Advanced English for Migrants, Job Pathway Program and Defence Force Reserve (MIAESR, 2001a; MIAESR, 2001b: 34). 
${ }^{\text {ix }}$ For persons first observed as a LMP participant in wave 1, the maximum number of observations is six. For persons first observed as a LMP participant in wave 2, the maximum number of observations is five and so on.

${ }^{\mathrm{x}}$ Among HA recipients, 207 (67\%) received CRA only, 76 (24\%) received public HA only and 27 (9\%) received both forms of assistance at different points in time during the data timeframe.

${ }^{\mathrm{xi}}$ So, for example, if the HA group has a higher incidence of workplace injuries than the comparison group, differences in employment rates will emerge even if the groups were identical in all respects at the time of enrolment in LMPs. The difference in employment rates eventuates for reasons unrelated to HA status, but would be falsely attributed to HA status.

xii Participants enrolling in a LMP in the financial year before wave 1 are treated as if they had enrolled in wave 1 for the purposes of calculating time interval computations. The time interval for HA recipients is 3 years, somewhat longer than the 2.5 year interval for the comparison group.

xiii The random effects model (1) is fitted by maximum likelihood using xtlogit with the option re in STATA.

xiv The null $H_{0} ; \psi^{2}>0$ is equivalent to the hypothesis $u_{i}=0$. The likelihood ratio test statistic comfortably rejects the null at $1 \%$, confirming the legitimacy of a person specific component in the error term (see the final row of Table 3 ).

${ }^{x v}$ The statistical significance of other variables in the model is unchanged by the inclusion of an IV, and coefficient estimates are stable. A sample restricted to persons starting LMP participation between 2001 and 2006 was used to test whether any employment gains (post-LMP participation) prove to be temporary. A variable measuring years since starting LMP is found to be positive in both random effects and IV versions of the panel model, but insignificant. In the IV model $\hat{\alpha}_{1}^{\prime}$ is again positive, but insignificant. Results are available from the author on request.

${ }^{x v i}$ Increasing age from 18 to 24 years raises the predicted probability of employment from $75 \%$ to $77 \%$; increasing age from 24 to 35 years lowers the predicted probability of employment from $77 \%$ to $71 \%$. There is then a sharp fall in predicted probability from $71 \%$ to $42 \%$ as age increases from 35 to 49 years.

${ }^{\text {xvii }}$ All variables other than calendar year (set equal to 2006) are set at mean values. 